\title{
Bush meat sold on the markets in Kisangani: analysis addressed to the right on species
} conservation in the Democratic Republic of the Congo

\author{
Olivier Basa $\mathrm{D}^{1}$, Casimir Nebesse $\mathrm{M}^{3}$, Consolate Kaswera $\mathrm{K}^{1,3}$, Judith Tsongo $\mathrm{M}^{1}$, \\ Sylvestre Gambalemoke $\mathrm{M}^{1,3,4}$, Benjamin Dudu $\mathrm{A}^{1,3}$, Lelo-Di-Makungu ${ }^{2}$
}

${ }^{1}$ Center for the monitoring of biodiversity, University of Kisangani, Kisangani, RD Congo

${ }^{2}$ Faculty of Law, University of Kisangani, P.O. Box 2012 Kisangani, DRC

${ }^{3}$ Faculty of Sciences of the University of Kisangani, P.O. Box 2012 Kisangani, DRC

${ }^{4}$ Higher Institute of Medical Techniques of Isiro P.O. Box 350 Isiro, DRC

\begin{abstract}
In order to identify the game species sold on the central market of Kisangani and to check up the respectability of the regulation of hunting by the Congolese population, we collected data from January to August 2009 and from December 2014 to May 2015. The results indicate that 29,525 game carcasses marketed, belong to 8 orders, 13 families and at least 27 species. On the central market of Kisangani, Artiodactyla (40.06\%) are the most sold followed by Primates

(37.79\%).

The family Bovidae (37.98\%) is the most

represented

followed by Cercopithecidae (37.61\%).

Based on

counting

carcasses,

Cercopithecus

sp (35.35\%), followed by Cephalophus

monticola (22.96\%) are the most sold. The Low $n^{\circ} 82-002$ which regulates hunting is not observed in Kisangani, as well as the ministerial decree $n^{\circ} 14 / 003$ of 11 February 2014 relating to the conservation of nature. In fact, the regular hunting period is not observed. In addition, Loxodonta africana, Manis gigantea, Okapia johnstoni, and Pan troglodytes which are totally protected, Cephalophus sylvicultor, Potamochoerus porcus, and Syncerus caffer nanus which are partially protected are exploited. Therefore, it is essential to implement mechanisms for integrated management of wild fauna which respect the Congolese legislation and international conventions.
\end{abstract}

Keywords - bush meat, law, conservation, Kisangani.

\section{INTRODUCTION}

In DRC, hunting is a main activity after agriculture for the majority of the Congolese population living in rural areas. Bush meat provides them with animal protein. In Kisangani, breeding is less practiced and occasionally it concerns poultry farm and small livestock. Kisangani is one of the Congolese towns with higher demographic pressure on forest resources, with approximately 1,186,479 inhabitants in 2009 and $1,602,144$ inhabitants in 2015 [1]. Urbanization has increased a strong demand for bush meat because breeding of small livestock, poultry and fishing alone cannot cover the needs in of animal protein. Indeed, hunting for subsistence or for commercial purposes, constitutes a threat to the whole ecosystem biodiversity of the Congo Basin forests [2].

Hunting has always provided rural population with bush meat protein. The low density of the population ensured the sustainability of hunting, a better protection and traditional management of natural resources. Today, this balance is disturbed as the population from the forest areas is growing as well as the development of the bush meat markets in DRC. In addition, because the legislation is not respected and/or unsuitable, the chain of bush meat is dominated by the informal sector. However, it participates as other activities to create a great number of jobs and the circulation of wealth throughout the extent of the country, from urban centers to the rural areas [3]. Bush meat is not a resource in free access. Each village controls a part of the forests intended for hunting, limits are determined on the basis of the density of the population [3].

Due to the crisis of governance in DRC as in Kisangani, the chain of bush meat is facing the management crisis. This bush meat management crisis is contributing to the extinction of some species with consequences for a large number of rural populations to loss their main source of animal protein and of their means of survival.

Therefore, the main goal of this study consists to identify animal species sold as game on the central market of Kisangani, to address the Congolese law 82-002 of 28 
May 1982 which regulates hunting in relation with sustainable management of bush meat in the region of Kisangani.

\section{MATERIAL AND METHODS}

The study was carried out on the central market of Kisangani, the capital city of the province of Tshopo. Kisangani has six communes which are Kabondo, Kisangani, Lubunga, Makiso, Mangobo, and Tshopo. Kisangani totalizes 1,602,144 inhabitants consisting of riparian, farmers and hunters [1]. The central market is located in the commune Makiso. Kisangani is crossed by the Tshopo River and the Congo River which facilitate the transport of goods, whaleboat, paddle-canoe or motorized-canoe [4].

The study is supported by data collected from January to August 2009 [5], from December 2014 to May 2015 [4], from December 2014 to May 2015 [6]. The data collected on bush meat in this period were analyzed regarding the legal tools.

\section{RESULTS}

\section{Organization of the sector}

From the hunters and/or the trappers in villages to the consumers in the city, the marketing chain seems to present very complex way as Babuchet and Ioveva [7] have recognized in the south of Cameroon.

Bush meat trade is part of the informal economy which escapes all control systems in the region of Kisangani. The official services concerned by the conservation of nature in their responsibility do not have reliable data. The owner of bush meat fixes the prices according to his immediate needs and financial means of the purchasers. The sector faces higher fiscal pressure (taxes, fees).

The institutional reform to enshrine biodiversity by the Constitution of 18 February 2006 remains unfinished. In the practice, sharing benefits among the central administration, the provinces and the territorial entities is unclearly defined. Conflicts of competence are observed throughout different administration levels which do not foster local development. The confusion of competences among the services of the National Economy to check the price and the services of the environment with a normative mission in the application of the legislation on the environment and the protection of wildlife.

Concerning the organization of the sector, it should be noted that in DRC, just as in other African countries of the Congo River basin, bush meat trade is organized around a long series of intermediaries and it is very rare that hunters themselves sell their catches on markets in the city [8].This complex chain indicates how the suppliers, the hunters, the sellers of the game interact in the organization of the hunting [9].

\section{Species collected as bush meat}

Proportion of animals sold as game on markets in Kisangani (data compared with the tables I, II and III of the Law n ${ }^{\circ} 82-002$ of 28 May 1982 on the regulation of hunting)

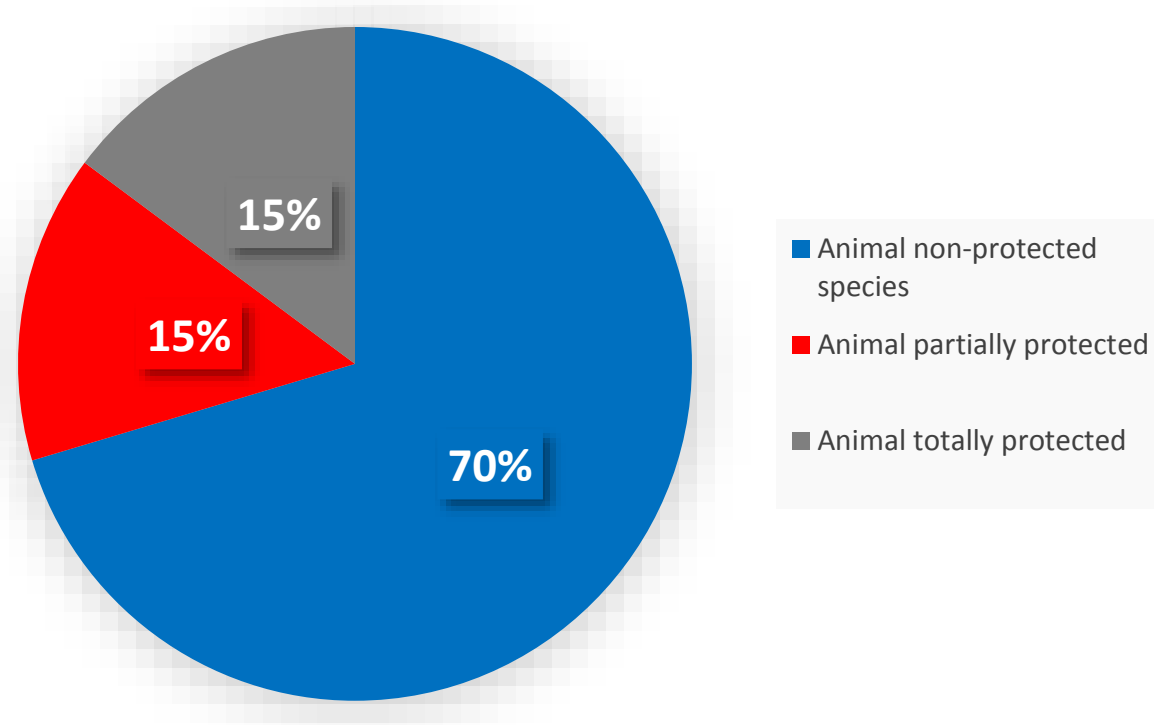

Fig. 1: proportion of species by animal partially protected, totally or not protected sold to markets of Kisangani

In DRC, the Law $\mathrm{n}^{\circ} 82-002$ of 28 May 1982 which regulates hunting distinguishes 3 categories of animals: the animals that are fully protected, animals partially protected and non-protected animals. The fig. (1) informs that on markets in Kisangani, all 3 categories of animals are sold: non-protected animal species come in head $(70 \%)$ followed animals fully protected (15\%) and animals partially protected (15\%). 
Techniques used by hunters and/or trappers in villages

Table.1: The capture techniques used.

Hunting techniques

Firearm : artisanal caliber 12 \& caliber 12 Baikal

War weapon :SMG, Mi-Mag \& AK 47

Traps built with creeper, nylon, metal cables and net

Total

Source: [9]

The artisanal caliber 12 and the industrial caliber 12 Baikal are actively used for commercial hunting (58.4\%) than for consumption (19.9\%). Traps built with nylon and metal cables enhance the effectiveness of trapping because of their resistance than the traditional traps made with creepers found in forests. Such traps contribute with $40.2 \%$ of game for commercial hunting against $80.1 \%$ for household consumption.

\section{Marketing of the bush meat}

In DRC, the Law $\mathrm{n}^{\circ} 82-002$ of 28 May 1982 which regulates hunting recognizes hunting for home consumption (including animal species partially protected, and non-protected animal species), and animal species fully protected [10]. In DRC, totally protected species are those which are also listed by the International Convention on the Species of Flora and Fauna threatened of extinction (CITES) and the ministerial decree $n^{\circ}$ 056/CAB/MIN/AFF-ECNPF/01/2000 of 28 March 2000 on the regulation of the international trade of endangered species of flora and fauna threatened of extinction. The trade of living wild animals protected cannot be done
Part of the sale

58.4

Part of the consumation (\%) 19.9

$\begin{array}{cc}1.4 & 0 \\ 40.2 & 80.1 \\ 100 & 100\end{array}$

without the approval of the Central Organ of CITES Management which delivers on payment of an special license. Partially protected species and non-protected species are those officially authorized for local consumption. The ministerial decree $\mathrm{n}^{\circ} 056$ has established the rules, and conditions of hunting, detention, trading and transporting such species (article 1). In fact, in DRC, all wild animals qualified as "the non-protected species" and their by-products for a commercial purpose might be killed as game only after obtaining an approval license issued by the Secretary General having hunting under his responsibility, by payment of a license of export or import. Article 81 of the Law $n^{\circ} 82-002$ of 28 May 1982 stipulates that the import or export of any protected species or any part non-perishable of one of these species is legally feasible only if the activity is covered by a legitimate certificate issued by the Department with the Hunting under his responsibility. Similarly CITES determines the import and export of animals as listed in third annex, to the prior grant and presentation respectively of a permit to import and export [10].

Table.2: Estimated number of carcasses of animals found on the markets.

\begin{tabular}{|c|c|c|c|c|c|}
\hline Order & Family & Genus / Species & $\begin{array}{l}\text { Protection } \\
\text { status }\end{array}$ & $\begin{array}{l}\text { Total of } \\
\text { carcasses }\end{array}$ & $\%$ \\
\hline \multirow{8}{*}{$\begin{array}{l}\text { Artiodactyla } \\
(\mathbf{4 0 . 0 6 \% )}\end{array}$} & \multirow{6}{*}{$\begin{array}{l}\text { Bovidae } \\
(37.98 \%)\end{array}$} & $\begin{array}{l}\text { Cephalophus } \\
\text { monticola (Thumberg, 1789) }\end{array}$ & ANP & 6778 & 22.96 \\
\hline & & $\begin{array}{l}\text { Cephalophus sp (C. H. Smith, } \\
\text { 1827) }\end{array}$ & ANP & 1840 & 6.23 \\
\hline & & $\begin{array}{l}\text { Cephalophus } \\
\text { sylvicultor (Afzelius, 1815) }\end{array}$ & APP & 33 & 0.11 \\
\hline & & $\begin{array}{l}\text { Cephalophus dorsalis (Gray, } \\
1846)\end{array}$ & ANP & 2526 & 8.56 \\
\hline & & Tragelaphus spekei & ANP & 83 & 0.28 \\
\hline & & $\begin{array}{l}\text { Syncerus caffer nanus (Sparman, } \\
1779 \text { ) }\end{array}$ & APP & 36 & 0.12 \\
\hline & $\begin{array}{l}\text { Suidae } \\
(1.23 \%)\end{array}$ & $\begin{array}{l}\text { Patamochoerus } \\
\text { porcus (Linnaeus, 1758) }\end{array}$ & APP & 362 & 1.23 \\
\hline & $\begin{array}{l}\text { Tragulidae } \\
(0.85 \%)\end{array}$ & $\begin{array}{l}\text { Hyemoschus aquaticus (Ogilby, } \\
1841 \text { ) }\end{array}$ & ANP & 250 & 0.85 \\
\hline
\end{tabular}




\begin{tabular}{|c|c|c|c|c|c|}
\hline & $\begin{array}{l}\text { Giraffidae } \\
(0.00 \%)\end{array}$ & $\begin{array}{l}\text { Okapia johnstoni (P. L. Sclater, } \\
\text { 1901) }\end{array}$ & ATP & 1 & 0.00 \\
\hline \multirow{7}{*}{$\begin{array}{l}\text { Primates } \\
(37.79 \%)\end{array}$} & \multirow{6}{*}{$\begin{array}{l}\text { Cercopithecidae } \\
(37,61 \%)\end{array}$} & $\begin{array}{l}\text { Cercopithecus } \\
\text { ascanius (Audebert, 1799) }\end{array}$ & ANP & 506 & 1.71 \\
\hline & & $\begin{array}{l}\text { Cercopithecus sp (Linneaus, } \\
1758 \text { ) }\end{array}$ & ANP & 10438 & 35.35 \\
\hline & & Papio anubis (Lesson, 1827) & ANP & 63 & 0.21 \\
\hline & & $\begin{array}{l}\text { Cercopithecus hamlyni (Pocock, } \\
\text { 1907) }\end{array}$ & ANP & 1 & 0.00 \\
\hline & & $\begin{array}{l}\text { Cercopithecus mitis (Wolf, } \\
\text { 1822) }\end{array}$ & ANP & 27 & 0.09 \\
\hline & & $\begin{array}{l}\text { Cercopithecus lhoesti (p. Sclater, } \\
\text { 1899) }\end{array}$ & ANP & 68 & 0.23 \\
\hline & $\begin{array}{l}\text { Hominidae } \\
(0.18 \%) \\
\end{array}$ & $\begin{array}{l}\text { Pan troglodytes (Blumenbach, } \\
\text { 1775) }\end{array}$ & ATP & 53 & 0.18 \\
\hline \multirow{2}{*}{$\begin{array}{l}\text { Rodentia } \\
(10.77 \%)\end{array}$} & $\begin{array}{l}\text { Cricetidae } \\
(8.95 \%)\end{array}$ & $\begin{array}{l}\text { Cricetomys emini (Wroughton, } \\
\text { 1910) }\end{array}$ & ANP & 2643 & 8.95 \\
\hline & $\begin{array}{l}\text { Hystricidae } \\
(1.82 \%)\end{array}$ & $\begin{array}{l}\text { Atherurus africanus (Gray, } \\
1842 \text { ) }\end{array}$ & ANP & 537 & 1.82 \\
\hline $\begin{array}{l}\text { Chiroptera } \\
(8.99 \%)\end{array}$ & & Eidolon helvum (Kerr, 1792) & ANP & 2655 & 8.99 \\
\hline \multirow{3}{*}{$\begin{array}{l}\text { Pholidota } \\
(0.15 \%)\end{array}$} & \multirow{3}{*}{$\begin{array}{l}\text { Manidae } \\
(0.15 \%)\end{array}$} & Manis gigantea (Illiger, 1815) & ATP & 20 & 0.07 \\
\hline & & $\begin{array}{l}\text { Manis tetradactyla (Linneaus, } \\
1766 \text { ) }\end{array}$ & ANP & 6 & 0.02 \\
\hline & & Manis sp & ANP & 18 & 0.06 \\
\hline $\begin{array}{l}\text { Carnivora } \\
(0.05 \%)\end{array}$ & $\begin{array}{l}\text { Viverridae } \\
(0.05 \%)\end{array}$ & $\begin{array}{l}\text { Bdeogale nigripes (Pucheran, } \\
1855 \text { ) }\end{array}$ & ATP & 14 & 0.05 \\
\hline $\begin{array}{l}\text { Proboscidea } \\
(0.01 \%)\end{array}$ & $\begin{array}{l}\text { Elephantidae } \\
(0.01 \%)\end{array}$ & $\begin{array}{l}\text { Loxodonta } \\
\text { africana (Blumenbach, 1797) }\end{array}$ & ANP & 2 & 0.01 \\
\hline \multirow[t]{4}{*}{$\begin{array}{l}\text { Crocodilian } \\
(\mathbf{0 . 0 0 \% )}\end{array}$} & $\begin{array}{l}\text { Crocodilidae } \\
(0.00 \%)\end{array}$ & Crocodylus sp & ANP & 1 & 0.00 \\
\hline & & $\begin{array}{l}\text { Epomops franqueti (Tomes, } \\
\text { 1836) }\end{array}$ & ANP & 150 & 0.51 \\
\hline & & $\begin{array}{l}\text { Hypsignathus } \\
\text { monstruosus H. (Allen, 1861) }\end{array}$ & APP & 414 & 1.40 \\
\hline & & Total & $\mid / / I I / /$ & 29525 & 100 \\
\hline
\end{tabular}

Source: [4], [5] and [6]

Key: ATP: Animal totally protected; APP: Animal partially protected; ANP: Animal non-protected species. The table 2 shows that 29,525 carcasses of game have been inventoried on markets in Kisangani. They represent 8 orders, 13 families and at least 27 species. Artiodactyla are the most sold (40.06\%), followed successively by Primates (37.79\%), Rodentia (10.77\%), Chiroptera $(8.99 \%)$, Pholidota $(0.15 \%)$, Carnivora $(0.05 \%)$, Proboscidea $(0.01 \%)$ and of Crocodilian $(0.00 \%)$.

The family Bovidae (37.98\%) which occupies the first place, is respectively followed by the families Cercopithecidae (37.61\%), Cricetidae (8.95\%), Hystricidae (1.82\%), Manidae (0.15\%), Viverridae (0.05 $\%)$, Elephantidae $(0.01 \%)$ and Crocodilidae $(0.00 \%)$. The genus Cercopithecus (35.35\%; 10,438 carcasses) occupies the head of the ranking followed by Cephalophus monticola (22.96\%: 6,778 carcasses) and Crocodylus (1 carcass).

The table indicates also all the three categories of animal are hunted as games: Pan troglodytes, Okapia johnstoni, Loxodonta africana, Cephalophus sylvicultor, Manis gigantea, M. tetradactyla, Crocodylus sp are totally protected species; Tragelaphus spekei, Cercopithecus hamlyni are partially protected, and all the others are the non-protected species authorized for local consumption.

\section{DISCUSSION AND CONCLUSION}

Three categories of animals (totally protected species, partially protected species, and non-protected species) are hunted as games and sold on markets in Kisangani based 
on legal instruments, both national and international which regulate the chain of bush meat. Clearly, these legal instruments are not observed in Kisangani. Fargeot [11] revealed that the Artiodactyla, and in particular the duikers suffer from the strongest levy of trade. Observation from FAO [12] revealed also that today more sophisticated techniques and non-selective are used by professional hunters and amplify game destruction.

In DRC, hunting regulation is not respected either by official authorities and local hunters in villages. The techniques and procedures prohibited by the Law $n^{\circ} 82$ are always used to hunt. In effect, the Law $n^{\circ} 82$ in reference with article 21 prohibits the use of the following devices for hunting:

1. the automatic weapon firing in bursts, the projectiles containing explosives, the guns TUE-Fauves and rifles fixed;

2. the luminous device or equipped with dazzling lights or any device illuminating;

3. the collars and the laces and metal threads of netting;

4. the poisons and other toxic products;

5. the circular light wrap;

6. the weapon manufactured illegally;

7. the weapon and ammunitions of war component or having dialed the arming regulatory framework of FARDC, gendarmerie, military or police affairs;

8. the striped weapon with a caliber of less than $6.5 \mathrm{~mm}$ if hunting concerns animals other than birds, rodents, small monkeys and small carnivores that are not protected;

9. the smooth weapon of some caliber as it is or the striped weapon with a caliber of less than $9 \mathrm{~mm}$ for hunting large game.

On the other side, the Law $\mathrm{n}^{\circ} 82$, in reference with article 23 , except by derogation of the hunting department authority, it is prohibited to import, to hold, to expose for sale, to transfer or to receive in any title and to transport or to peddle traps or device prohibited. The ministerial decree $n^{\circ}$ 014/CAB/MIN/ENV/2004 of 29 April 2004 concerning measures of execution of the Law $n^{\circ} 82$ also prohibits the use of hunting-spears as well as pits.

Indeed, in Kisangani, the exploitation of the game is not respected in regard to the relevant species concerned. The first decree of 21 April 1937 during colonial era on the preservation of wildlife, the regime of hunting and fishing constitutes the basic of all the texts elaborated later for the management of forests and the hunting process [10]. This decree was revised on 15 January 1957, and later amended by the Legislative decree $n^{\circ} 52-273$ of 24 June 1958, the Decree of 27 June 1960, and the Law $\mathrm{n}^{\circ} 82$. Today, this Law is facing a growing crisis due to the failure of good policy coordination of the laws, production and the implementation measures, of suitable governance based on convergence between the different complementary sectors involved in the promotion of the right of hunting in DRC.

The promulgation of the Congolese Forest Code $n^{\circ}$ 011/2002 on 29 August 2002, the ministerial decree $n^{\circ}$ 056 of 28 March 2000 on the regulation of the International Trade of species of Fauna and Flora in danger of extinction (CITES) of 6 March 2001 laying down the sampling periods of the parrot-gray in DRC, the adoption of the ministerial decree $\mathrm{n}^{\circ} 014 / \mathrm{CAB} / \mathrm{MIN} / \mathrm{ENV} / 2004$ of 29 April 2004 related to the application measures of the Law $n^{\circ} 82-002$ of May 28 1982, all reinforce the new framework of the Congolese legislation in the field of preservation of the wildlife, and all have played an important role that led to the adoption of the decree $n^{\circ} 14 / 003$ relating to the conservation of the nature of 11 February 2014. However, there is not an approach effective jurisprudence on the part of the Congolese legislator.

The Law $n^{\circ} 82$ is based on the principle of exploitation of wildlife rather than on its protection. Better to say, it is subject to an ambiguous interpretation concerning the local community authority and the parties in the presence. The consequence is a bad exploitation the fauna resources which is leading to the loss of the flagship species in DRC.

Hunting is positioned on the list of informal activities and in fact, it is beyond doubt out of the control of the official authorities as on markets in Kisangani all the three categories of animals are hunt for meat, e.g. the totally protected species (Okapia johnstoni, Pan troglodytes, Loxodonta africana, Manis gigantea, etc.), the partially protected species (Syncerus caffer nanus, Potamochoerus porcus, etc.), and the non-protected species. Probably, this list is not exhaustive as usually the smoked-carcasses represent at least $95 \%$ of the stock sold $[4,5,6]$. All of them have not been identified to the rank of species to be compared with the list in the three annexes of the Law $n^{\circ} 82$. The Congolese Law $n^{\circ} 82-002$ to regulate hunting is not respected regarding the games listed as "non-protected species" in annex III. In reality, these species are placed under the regime which regulates the opening period and closing period for hunting.

Fargeot [2] reported that the legislation to be applied and the attitudes of hunters are generally confused, and the entire chain of bush meat is completely managed as informal activity. These attitudes indicate that the hunting pressure on games is uncontrolled.

To conclude, due to the higher exploitation of bush meat based on the whole different laws on nature conservation in DRC, the sustainability of the species is threatened. Our study recommends quickly to respect the Congolese legislation and international conventions governing the conservation of nature and to implement mechanisms for 
integrated management of wildlife, in order to better durable conservation of biodiversity for present and future generations.

\section{REFERENCES}

[1] INS/PO (2016) 'Estimation de la Direction Provinciale de l'INS/PO de la population de la Province Orientale par sexe de 1957-2015, Direction Provinciale de l'INS/PO, pp. 1-13.

[2] Fargeot, C. (2004) 'La chasse commerciale en Afrique centrale I. La venaison ou le négoce d'un produit vivrier.', Bois et Forêts Tropiques, 282(4), pp. 27-40.

[3] Fargeot, C. (2011) 'La viande de chasse en Afrique Centrale', Cirad, $2 p$.

[4] Nebesse, M.; Van Vliet, N.; Gambalemoke, M.; Mambweni, M. ; Nazi, R. et Dudu, A. (2014) 'Etat de gibiers livrés et commercialisés au marché central de kisangani : principaux axes de provenance, moyens de transports et techniques de captures utilisées', Ann. Fac. Sci. $16: 1$ (2014) : pp. 254-278.

[5] Kakuru, B. (2010) 'Etat actuel du marché des gibiers à Kisangani (Province orientale, RDC), mémoire inédit, Faculté des Sciences, Université de Kisangani, 33p.

[6] Fatima, M-.P., (2015) 'Etude de flux de la viande de brousse sur les marchés IAT, Djubu-djubu et Kikongo à Kisangani: décembre 2014 à mai 2015', mémoire inédit, Faculté des Sciences, Université de Kisangani, 43p.

[7] Bahuchet, S. and Ioveva, K. (2000) 'De la forêt au marché: le commerce de gibier au sud Cameroun', L'Homme et la forêt tropicale, Marseille : Société d'écologie humaine, pp. 533-558.

[8] Binot, A. et Cornelis, D. (2004) 'Synthèse bibliographique du secteur "viandes de brousse" au Gabon', CIRAD-EMVT, ECONAP/Biodiversité animale, Rapport Cirad-emvt n ${ }^{\circ}$ 04-14, pp. 1-106.

[9] Nebesse Mololo (2016) 'Exploitation et caractérisation de la viande de brousse prélevée au village Basukwambula (PK 92) et au village Baego (PK 147) sur l'axe Kisangani-Ituri» (Province de la Tshopo, R.D.Congo)' Mémoire DES inédit, Faculté des Sciences, Université de Kisangani, 84p.

[10]Riat, S. (2007) 'Etude comparative des textes législatifs et réglementaires relatifs à la gestion de la faune et de la chasse dans cinq pays du bassin du Congo: Cameroun, Congo, Gabon, RCA et RDC', Silva/Riat, p. 155.

[11] Fargeot, C. (2005) 'La chasse commerciale en Afrique centrale II. Une activité territoriale de rente', Bois et Forêts des Tropiques, 283(1), p. 65. Available http://publications.cirad.fr/download.php?dk=52419
$5 \&$ doc $=15018 \% 5 \mathrm{Cnhttp}: / /$ bft.revuesonline.com/grat uit/BFT_283_65-80.pdf.

[12]FAO (2006) 'Chasse et gibier', Nature \& Faune, 21(1), pp. 1-70. 